\title{
PERUBAHAN ANTI NUTRISI PADA SILASE BUAH SEMU JAMBU METE SEBAGAI PAKAN DENGAN MENGGUNAKAN BERBAGAI ARAS TEPUNG GAPLEK DAN LAMA PEMERAMAN
}

\section{CHANGE OF ANTINUTRITIVE VALUE OF CHESTNUT FRUIT (Anacardium occidentale) SILAGE IN COMBINATION WITH VARIOUS LEVEL OF CASSAVA MEAL ADDITION AND TIME OF FERMENTATION}

\author{
Bernadete Barek Koten* \\ Program Studi Teknologi Pakan Ternak, Politeknik Pertanian Negeri Kupang, Jl. Adisucipto Penfui Kupang, NTT
}

\section{INTISARI}

Penelitian dengan tujuan mengevaluasi kadar anti nutrisi dari silase buah semu jambu mete sebagai pakan dengan menggunakan berbagai aras tepung gaplek dan lama pemeraman yang berbeda telah dilaksanakan selama 8 bulan di Desa Ratulodong, Kecamatan Tanjung Bunga, Kabupaten Flores Timur dan Laboratorium Nutrisi dan Pakan Ternak Politeknik Pertanian Negeri Kupang Nusa Tenggara Timur. Penelitian ini dirancang dengan rancangan acak lengkap pola faktorial dengan aras gaplek sebagai faktor pertama yang terdiri dari 0, 3, 6, 9\% dan lama pemeraman sebagai faktor kedua yang terdiri dari 20, 40, dan 60 hari. Variabel yang diamati adalah kadar tanin dan kadar asam fitat. Hasil penelitian menunjukkan bahwa teknologi silase secara sangat nyata $(\mathrm{P}<0,01)$ dapat menurunkan zat anti nutrisi buah semu jambu mete. Kadar tanin tertinggi pada silase tanpa aras gaplek dengan lama penyimpanan 20 yaitu 0,35\%, sedangkan yang terendah pada silase tanpa aras gaplek dengan lama pemeraman 40 hari yaitu 0,06\%. Kadar asam fitat tertinggi pada perlakuan aras gaplek 9\% dengan lama pemeraman 40 hari yaitu 5,48\%, sedangkan yang terendah pada silase dengan aras gaplek 6\% dan lama penyimpanan 20 hari yaitu 2,38\%. Kadar tannin dan asam fitat ini mengalami penurunan selama proses fermentasi dibandingkan dengan yang ada pada buah semu jambu mete segar. Disimpulkan bahwa teknologi silase dapat meningkatkan nilai manfaat buah semu jambu mete sebagai pakan ternak karena mampu menurunkan zat anti nutrisi. Silase buah semu jambu mete dengan zat anti nutrisi yang paling rendah terdapat pada perlakuan tanpa tepung gaplek yang diperam selama 60 hari.

(Kata kunci: Silase, Buah semu jambu mete, Lama pemeraman, Tepung gaplek, Tanin, Asam fitat)

\begin{abstract}
The objective of this experiment was to evaluate antinutritive value of chestnut fruit silage in combination with various level of cassava meal addition and time of fermentation. The study was conducted for 8 month at Ratulodong countryside, district of Tanjung Bunga and at Nutrition and Fodder Laboratory. This experiment was conducted in 2 treatment factors with 3 replication. The first factor was various level of cassava meal e.i. 0, 3, 6, and 9\%, and the second factor was time of fermentation e.i. 20,40, and 60 days. The result showed that silage technonogy with various cassava meal level and fermentation time significantly $(P<0.01)$ decreased antinutritive value of chestnut fruit. Tannin content decreased in line with increasing level of cassava meal and time of fermentation. Higher tannin at $0 \%$ cassava meal with fermentation time of 20 days (0.35\%), and lower at 3\% cassava meal with fermentation time of 40 days (0.06\%). The highest phytic acid content at $9 \%$ cassava meal with fermentation time of 40 days (5.48\%), and the lowest at $6 \%$ cassava meal with fermentation time of 20 days (2.38\%). Tannin and phytic acid content were decreased during fermentation process and lower than fresh fruit chestnut. It could be concluded that silage technonogy could be applied at chestnut fruit. This technology increased the benefit of chestnut fruit as feed ingredient because it decreased antinutritive value. The lowest antinutritive value at $0 \%$ cassava meal with fermentation time of 60 days.
\end{abstract}

(Key words: Silage, Chestnut fruit, Cassava meal, Fermentation time, Tannin, Phytic acid)

\section{Pendahuluan}

Buah semu jambu mete (Anacardium occidentale) dapat diandalkan untuk pakan dalam rangka mengatasi kekurangan pakan yang biasa

\footnotetext{
* Korespondensi (corresponding author):

Telp.+62 85292869170

E-mail: bernadete_koten@yahoo.com
}

terjadi, terutama pada saat musim kemarau panjang seperti di Nusa Tenggara Timur (NTT). Nilai nutrisi buah semu jambu mete segar adalah 84,4-90,4\% kadar air, lemak 0,02-0,5\%, protein $0,1-0,9 \%$, karbohidrat 0,8-2\%, vitamin C 0,14-0,37\%, 0,01-2 mg Ca, 0,00-19,9 mg $\mathrm{P}$, dan 6,7-10,6\% gula reduksi (Cahyono, 2001 cit. Bora et al., 2006).

Komoditi jambu mete ini sudah tersebar di seluruh kabupaten di NTT, maka jika buah semunya 
diolah dengan baik, pemanfaatannya sebagai pakan dapat dirasakan di seluruh wilayah NTT. Produksi buah semu di NTT sebanyak 432.955,47 ton (Badan Pusat Statistik, 2006). Pemanfaatannya baru sekitar 20\% dari jumlah tersebut sebagai bahan pangan (Sumangat et al., 1991). Berdasarkan perhitungan, di NTT buah semu yang sudah termanfaatkan sekitar 86.591 ton dan yang terbuang sebanyak 346.364 ton. Pengamatan penulis, banyak gundukan buah semu yang rusak, berada dalam areal perkebunan jambu mete. Buah jambu mete yang berlimpah dan terbuang tersebut dapat dimanfaatkan sebagai pakan.

Salah satu faktor pembatas pemanfaatan buah semu sebagai pakan adalah rasa sepat akibat adanya tanin dan rasa gatal karena kandungan asam urushiol serta asam fitat. Tanin, asam fitat, dan asam urushiol dapat menghambat konsumsi, pencernaan dan absorbsi nutrisi yang tentunya akan berdampak pada produktivitas ternak. Rossi (1998) cit. Koten et al. (2007) melaporkan bahwa ternak kambing tidak dapat mengkonsumsi buah semu jambu mete lebih dari 20\% karena terkendala pada anti nutrisi ini.

Tanin akan menurunkan konsumsi pakan akibat rasa sepat yang ada, dan akan mengikat protein pakan pada intestinum yang menyebabkan penurunan daya cerna dan absorbsi protein. Asam fitat akan menghambat absorbsi kalsium akibat pembentukan kalsium yang tidak larut sehingga menghambat penyerapan mineral (Widodo, 2005).

Teknologi yang tepat untuk mengolah buah ini pada musim kelimpahan dan mampu mengurangi kadar tanin serta asam fitat dari buah semu jambu mete sangat diperlukan. Salah satu teknologi yang direkomendasikan adalah pengolahan/pengawetan dalam bentuk silase. Proses fermentasi dapat memperbaiki sifat dasar bahan pakan seperti meningkatkan kecernaan, menghilangkan senyawa beracun/anti nutrisi, menghilangkan bau dan meningkatkan flavor (Suliantari dan Rahayu, 1990).

Pembuatan silase memerlukan bahan berkarbohidrat mudah tercerna tinggi sebagai media hidup bagi organisme yang melakukan fermentasi (Koten dan Yoku, 2003). Salah satu bahan tersebut adalah tepung gaplek. Kandungan pati tepung gaplek 63-71\%, sehingga diharapkan dapat menjadi sumber energi bagi mikrorganisme yang melakukan fermentasi. Banyaknya tepung gaplek yang ditambahkan dalam silase buah semu jambu mete dan lamanya pemeraman menentukan tingkat fermentasi yang terjadi yang nantinya akan berpengaruh terhadap kandungan tanin dan asam fitat silase buah semu jambu mete.

Informasi tentang efektivitas teknologi silase dalam menurunkan zat anti nutrisi, terutama kadar tanin dan asam fitat buah semu jambu mete, belum banyak diketahui. Untuk itu telah dilakukan suatu penelitian tentang perubahan kadar tanin dan asam fitat pada silase buah semu jambu mete dengan berbagai aras tepung gaplek dan lama pemeraman.

Penelitian ini bertujuan untuk mengevaluasi perubahan kadar tanin dan asam fitat dari buah semu jambu mete yang dibuat silase pada berbagai aras tepung gaplek dan lama pemeraman.

\section{Materi dan Metode}

Penelitian ini telah dilaksanakan di Desa Ratulodong Kecamatan Tanjung Bunga Kabupaten Flores Timur dan di Laboratorium Nutrisi dan Pakan Ternak Politeknik Pertanian Negeri Kupang NTT, selama 8 bulan mulai bulan Maret sampai November 2008.

Bahan yang digunakan adalah buah semu jambu mete yang telah matang dan segar serta tepung gaplek. Peralatan yang digunakan dalam penelitian ini adalah stoples sebagai silo dengan isi 2 kg sebanyak 36 buah, timbangan elektrik dengan kapasitas 2,8 kg dan skala terkecil 0,1 g untuk menimbang tepung gaplek, buah semu jambu mete dan silase yang rusak, serta timbangan analitik untuk menimbang sampel, baskom, rak penjemur, $\mathrm{pH}$ meter, pisau, oven pengering dengan suhu $60^{\circ} \mathrm{C}$.

Penelitian ini dirancang menggunakan Rancangan Acak Lengkap pola Faktorial (Steel dan Torrie, 1993) dengan dua faktor perlakuan yaitu perlakuan I aras tepung gaplek dan perlakuan kedua adalah lama waktu fermentasi. Perlakuan aras tepung gaplek tersebut adalah:

L1 = tanpa tepung gaplek

L2 = aras tepung gaplek 3\% dari berat kering buah semu,

L3 $=$ aras tepung gaplek 6\% dari berat kering buah semu,

L4 = aras tepung gaplek 9\% dari berat kering buah semu.

Perlakuan lama fermentasi terdiri dari :

$$
\begin{aligned}
& \mathrm{W} 1=20 \text { hari } \\
& \mathrm{W} 2=40 \text { hari } \\
& \mathrm{W} 3=60 \text { hari }
\end{aligned}
$$

Terdapat 4 × $3=12$ kombinasi perlakuan dengan 3 kali ulangan sehingga terdapat 36 unit percobaan.

Penelitian dimulai dengan membersihkan buah semu dan mengirisnya dengan ketebalan \pm 1 $\mathrm{cm}$, selanjutnya dijemur hingga mencapai kadar air $50 \%$. Buah semu yang telah kering tersebut dicampur dengan tepung gaplek sesuai perlakuan, selanjutnya dipadatkan dalam silo (stoples). Stoples kemudian ditutup rapat-rapat untuk menjamin keadaan anaerob. Silase tersebut kemudian diperam sesuai dengan perlakuan lama pemeraman. Silo selanjutnya dibongkar sesuai dengan perlakuan lama pemeraman. Pengamatan dilakukan terhadap 
silase sesaat setelah pembongkaran dilakukan. Sampel silase buah semu tersebut diambil, dipreparasi (digiling halus) untuk selanjutnya dianalisis kadar tanin dan kadar asam fitat.

Variabel yang diamati dari penelitian ini adalah kadar anti nutirisi silase buah semu jambu mete yang meliputi kadar tanin (\%) dan kadar asam fitat (\%). Data yang diperoleh diolah dengan analisis variansi dilanjutkan dengan uji DMRT dengan SPSS versi 16.

\section{Hasil dan Pembahasan}

\section{Kadar tanin silase buah semu jambu mete}

Kadar tanin silase buah semu jambu mete ternyata sangat dipengaruhi $(\mathrm{P}<0,01)$ oleh aras gaplek dan lama pemeraman. Rerata kadar tanin silase buah semu jambu mete akibat perlakuan disajikan pada Tabel 1.

Kadar tanin tertinggi dengan perlakuan gaplek terlihat pada L1 diikuti dan berbeda dengan L3, L2 dan yang terendah pada L4. Pada perlakuan lama pemeraman, kadar tanin tertinggi pada W1 yang berbeda $(\mathrm{P}<0,01)$ dengan $\mathrm{W} 2$, dan yang terendah pada W3. Interaksi perlakuan aras gaplek dan lama pemeraman, kadar tanin tertinggi pada L1W1 dan yang terendah pada L2W3. Terlihat bahwa kadar tanin makin berkurang dengan semakin tingginya aras gaplek dan semakin lamanya pemeraman.

Berkurangnya kadar tanin pada silase buah semu jambu mete ini diduga disebabkan oleh terurainya senyawa polifenol (tanin) tersebut akibat pengirisan buah semu dan rendahnya $\mathrm{pH}$ akibat aktivitas fermentasi bakteri asam laktat pada proses ensilase. Koten et al. (2007) melaporkan bahwa pH silase buah semu jambu mete berkisar dari 3,71 sampai 4,14 dengan rerata 3,93. Hal ini sesuai dengan pendapat Widodo (2005) yang menyatakan bahwa pengaruh tanin dapat dihilangkan dengan perendaman dalam air, perendaman dalam larutan alkali, cara mekanis, dan suplementasi donor metal.
Teknologi silase ternyata mampu menurunkan kadar tanin sebanyak 78,33\%, yang tercermin pada kadar tanin buah semu jambu mete segar sebanyak $0,60 \%$ berkurang menjadi $0,13 \%$ setelah diolah menjadi silase.

Rerata kadar tanin silase jambu mete yang dihasilkan dalam penelitian ini adalah 0,13\%. Kadar tanin ini lebih rendah daripada kadar tanin biji asam yaitu 5,72\% seperti yang dilaporkan oleh Koten (2006).

\section{Kadar asam fitat silase buah semu jambu mete}

Kadar asam fitat silase buah semu jambu mete ternyata sangat dipengaruhi $(\mathrm{P}<0,01)$ oleh aras gaplek dan lama pemeraman (Tabel 2). Perlakuan aras gaplek menunjukkan kadar asam fitat tertinggi pada L3 yang diikuti dan berbeda dengan L4, L2 dan yang terendah pada L1. Perlakuan lama pemeraman menunjukkan kadar asam fitat tertinggi pada W2 yang berbeda $(\mathrm{P}<0,01)$ dengan $\mathrm{W} 3$, dan yang terendah pada W1. Interaksi perlakuan aras gaplek dan lama pemeraman menghasilkan kadar asam fitat tertinggi pada L4W3 yang diikuti oleh L2W3 dan yang terendah pada L1W3.

Terlihat bahwa kadar asam fitat semakin berkurang dengan semakin tingginya lama pemeraman, akan tetapi semakin tinggi aras gaplek justru meningkatkan kadar asam fitat silase. Pemeraman yang makin lama memungkinkan aktivitas fermentasi semakin lama yang menyebabkan terurainya ikatan asam fitat ini sehingga makin menurunkan kadarnya. Widodo (2005) menjelaskan bahwa cara fermentasi dapat membebaskan fosfat dari asam fitat. Kondisi ini menguntungkan bagi ternak yang mengkonsumsi silase buah semu tersebut.

Asam fitat yang semakin tinggi sejalan dengan makin tingginya aras gaplek mungkin disebabkan adanya tambahan asam fitat dari tepung gaplek. Tabel 2 menunjukkan bahwa pada silase buah semu jambu mete yang tanpa ditambahkan 2,77\% dan 2,38\%. Koten (2006) melaporkan bahwa kadar asam fitat buah jambu mete yang segar adalah

Tabel 1. Rerata kadar tanin silase buah semu jambu mete dengan penambahan tepung gaplek dan lama peram yang berbeda (\%) (average of tannin content of chestnut fruit silage with different level of cassava meal addition and incubation periodes (\%))

\begin{tabular}{ccccc}
\hline \hline Aras penambahan gaplek (\%) & \multicolumn{3}{c}{ Lama pemeraman (hari) (time of fermentation (day)) } \\
\cline { 2 - 5 } (cassava meal addition (\%)) & 20 & 40 & 60 & Rerata (average) \\
\hline 0 & $0,35 \pm 0,02$ & $0,06 \pm 0,00$ & $0,09 \pm 0,01$ & $0,23 \pm 0,10^{\mathrm{D}}$ \\
3 & $0,20 \pm 0,01$ & $0,12 \pm 0,00$ & $0,08 \pm 0,00$ & $0,09 \pm 0,03^{\mathrm{B}}$ \\
6 & $0,12 \pm 0,00$ & $0,12 \pm 0,00$ & $0,08 \pm 0,01$ & $0,10 \pm 0,02^{\mathrm{C}}$ \\
9 & $0,09 \pm 0,00$ & $0,08 \pm 0,00$ & $0,08 \pm 0,00$ & $0,08 \pm 0,00^{\mathrm{A}}$ \\
Rerata (average) & $0,16 \pm 0,12^{\mathrm{b}}$ & $0,11 \pm 0,06^{\mathrm{a}}$ & $0,11 \pm 0,02^{\mathrm{a}}$ & \\
\hline
\end{tabular}

a,b Superskrip yang berbeda pada baris yang sama menunjukkan perbedaan $(\mathrm{P}<0,01)$ (different superscripts at the same row indicate significant differences $(P<0.01))$.

$\mathrm{A}, \mathrm{B}, \mathrm{C}, \mathrm{D}$ Superskrip yang berbeda pada kolom yang sama menunjukkan perbedaan $(\mathrm{P}<0,01)$ (different superscripts at the same column indicate significant differences $(P<0.01))$. 
Tabel 2. Rerata kadar asam fitat silase buah semu jambu mete dengan penambahan tepung gaplek dan lama peram yang berbeda (\%) (average of phytic acid content of chestnut fruit silage with different level of cassava meal addition and incubation periodes (\%))

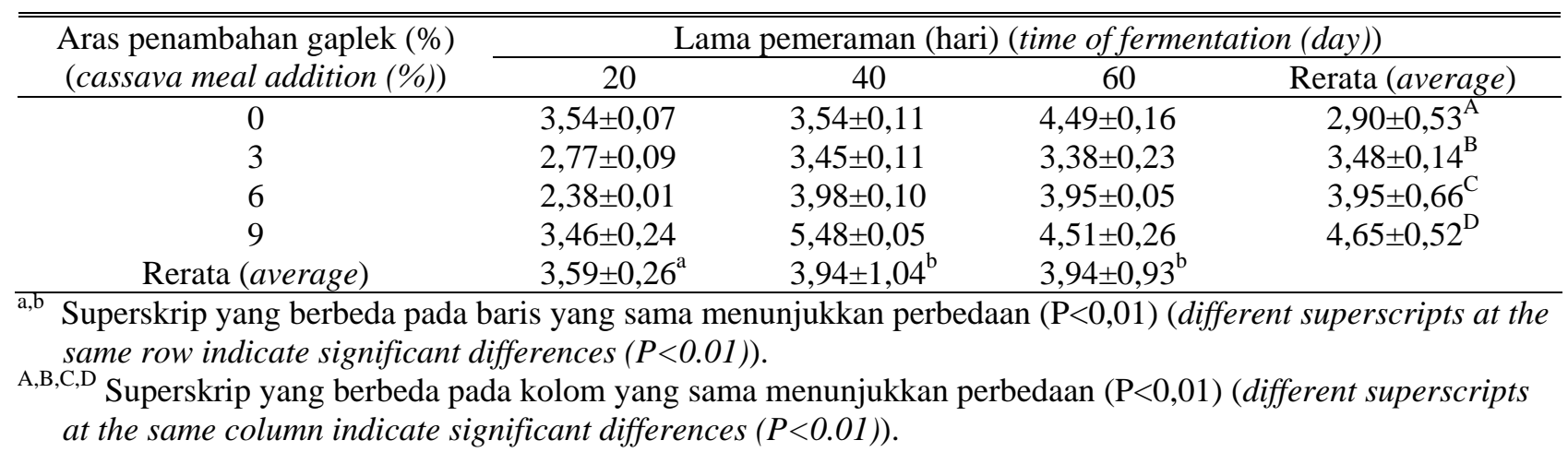

$3,71 \%$. Artinya proses silase ternyata mampu menurunkan kadar asam fitat sebesar 4,31\%, 25,34\%, dan 35,85\% Rerata kadar asam fitat silase jambu mete yang dihasilkan dalam penelitian ini adalah 3,58\%. Kadar asam fitat ini lebih tinggi daripada kadar asam fitat buah semu jambu mete segar yaitu 3,71\% seperti yang dilaporkan oleh Koten (2006). Kadar asam fitat buah semu jambu mete ini, baik dalam bentuk segar maupun setelah menjadi silase, lebih tinggi daripada kadar asam fitat dari bungkil kedelai yaitu $1,00-1,47 \%$ tetapi berada dalam kisaran kadar asam fitat dari bungkil biji kapas yaitu 2,86-4,29\%.

\section{Kesimpulan}

Teknologi silase dapat meningkatkan nilai manfaat buah semu jambu mete sebagai pakan ternak karena mampu menurunkan anti nutrisi. Silase buah semu jambu mete dengan anti nutrisi yang paling rendah terdapat pada silase tanpa tepung gaplek yang diperam selama 60 hari.

Teknologi silase dapat diaplikasikan pada buah semu jambu mete karena dapat meningkatkan nilai manfaat buah semu jambu mete sebagai pakan ternak karena meningkatkan nilai nutrisi dan mampu menurunkan anti nutrisi, dan untuk menghasilkan buah semu jambu mete dengan anti nutrisi terendah, silase buah semu jambu mete tanpa gaplek yang diperam selama 60 hari memberikan hasil yang terbaik.

\section{Ucapan Terima Kasih}

Ucapan terima kasih disampaikan kepada Politeknik Pertanian Negeri Kupang atas Dana Penelitian Rutin Tahun 2008 yang telah membiayai penelitian ini.

\section{Daftar Pustaka}

Bora, N., Kartiwan, dan S. Bunga. 2006. Pemberian Asam benzoat terhadap kualitas dan daya simpan sirup jambu mete. Laporan Penelitian. Politeknik Pertanian Negeri Kupang. Kupang

Badan Pusat Statistik. 2006. Nusa Tenggara Timur dalam Angka. Badan Pusat Statistik Propinsi Nusa Tenggara Timur, Kupang.

Koten, B.B. dan O. Yoku. 2003. Silase untuk konservasi hijauan. PARTNER. Buletin Pertanian Terapan. Tahun 10 No 2. Edisi Juli 2003. Politeknik Pertanian Negeri Kupang.

Koten, B.B. 2006. Analisis zat nutrien dalam pakan ternak. Laporan Kegiatan Magang di Fakultas Teknologi Pertanian UGM. Jurusan Peternakan Politeknik Pertanian Negeri Kupang.

Koten, B.B., R. Wea, dan T.N.I. Koni. 2007. Produksi dan kualitas silase buah semu jambu mete pada berbagai level tepung gaplek dan lama pemeraman. Laporan Penelitian. Politeknik Pertanian Negeri Kupang.

Steel, R.G.D. dan J.H. Torrie. 1993. Prinsip Dasar Prosedur Statistika. Suatu Pendekatan Biometrik. Penerbit Gramedia Pustaka Utama. Jakarta.

Suliantari dan W.P. Rahayu. 1990. Teknologi Fermentasi Umbi-umbian dan Biji-bijian. Pusat Antar Universitas Pangan dan Gizi. IPB-Bogor.

Sumangat, D.E., Mulyanta, dan Abdullah. 1991. Peningkatan nilai tambah petani jambu mete melalui pemanfaatan buah semu jambu mete di industri pedesaan. Makalah disajikan pada Aplikasi Teknologi Teknologi Pertanian Kupang, 20-24 Oktober 1991.

Widodo. W. 2005. Tanaman Beracun dalam Kehidupan Ternak. Universitas Muhammadiyah Malang Press. Malang. 